\title{
科学的理論化をめぐって
}

\section{On Scientific Theorizing}

\section{中村 和生 \\ NAKAMURA Kazuo}

This paper focuses on the problem of foundation in science. In order to approach this topic,Michael Lynch's criticism of Alfred Schutz's demarcation between common-sense rationality and scientific rationality is cited. From this, it is claimed that the demarcation to be examined is between science as working and scientific theorizing. Regarding the former, laboratory practices are discussed based on findings of laboratory studies. Regarding the latter, a theorizing in sociology is analyzed. By these double demonstrations, it is recognized that there is no such demarcation and no need for scientific foundation, and that we should study common-sense categories and 'scientific' practice in their own rights.

\section{1.はじめに}

社会学は、その創設以来、自らに「科学的」なる特性を付与しようという試みを展開し てきた。コントの知識の 3 段階説はもちろん、「社会的事実の客観的実在は社会学の根本 原理である」と唱えたデュルケームの方法論も、そうした方向性の下に捉えることができ る。例えばデュルケームは『自殺論』の冒頭において「実は日常語というものは、それに よってあらわされている概念と同じように、いつも曖昧なものだ。(中略) 学者は、研究 しようとする事実群に、科学的な取扱のために必要な同質性と特定性を与えるために、自 らそれを構成しなければならない。」Durkheim 1897=1985:17-8]と述べている。

このように常識的概念を科学的概念に修正していき、それによって自らの探求で得られ た知識を保証しようとする態度を、基礎づけ主義とここで呼んでおきたい。こうした基礎 づけ主義においては、科学と常識の弁別的な区別がたやすく主張できることになる。

ところで、こうしたデュルケームの方針に対して、常識的概念それ自体の秩序だった使 用に注目すべきことを最初に説いたのは、おそらくはアルフレッド・シュッツであろう。 シュッツが「社会科学者の構成する思惟対象は、人々のあいだで自らの日常生活を営んで いる人の常識的な思惟によって構成された思惟対象と関係し、そしてそれに基づけられて いる」[Schutz 1973=1983:52]と述べたことは、常識に対する態度において格段の進歩を社 会学にもたらしてくれた。常識的概念それ自体がいかに秩序だって用いられているのか、 このことはデュルケームの視野にはなかったからである。

しかし、常識的概念についてのシュッツの主張はそれを科学的概念にきちんと置き換え るためのものであった。つまり、常識的概念に基づいた人々の行動を「社会科学者が、自 らの携わる科学の手続き上の諸基準に従って観察し、説明しょうとする」[ibid.]ことにな る。この主張から、一見したところ進歩に思えたこうしたいき方は、結局のところ、デュ ルケームと同じく常識に対する修正主義的な態度をとり、科学的な基礎づけを鼓舞するも のになってしまっていることがわかる。 
本稿では、シュッッの科学論にさえも見られるこの科学の基礎づけ主義を問題としたい(1)。 つまり、ここで問いたいのは以下のことである。我々の学問的営為は、常識からは弁別的 に区別され、その常識に対して特権的な地位を持つ「科学」なるものによって基礎づけら れなければならないのか。そして、自然を対象にするのであれ、社会を対象にするのであ れ、既にこれまで行われてきた諸々の学問は、この弁別的な区別によってもたらされた基 礎づけによって確固たるものとなっているのか。

この問題にたいして以下の手順でアプローチしていきたい。まず、シュッッによる常識 と科学の弁別的区別をめぐってなされた議論を取り上げる。そこから、論じるべきトピッ クが、常識的特性を備える「労働行為としての科学」と「科学的理論化」との弁別的な区 別[Schutz 1962=1985:59]であることを引き出す。それゆえ、まずは労働行為としての科学 の事例として、実験室研究を取り上げる。次に、科学的理論化の事例として社会学の理論 化作業を取り上げる。そして、これら経験的研究に基づいて、科学と常識の弁別的区別の 是非とその含意を問いたい。

\section{M.リンチによるシュッツ科学論の批判}

まず、この目的の出発点としてM.リンチによるシュッツ科学論の批判[Lynch 1988]を用 いたい。リンチは、まず、科学と常識的合理性の弁別的な境界設定をシュッツが行ってい るとし、このことを中心にして科学に関するシュッツの諸主張を 5 つの提言によって定式 した。その上でこの提言と対照を成す反対提言を挙げて、そのことを証明してくれるもの として、科学の社会的研究(Social Studies of Science)や科学のエスノメソドロジー研究か ら様々な経験的知見を引き合いに出した[Lynch 1988:82] (2)。その提言と反対提言は以下の ようになる。

提言

1. 諸科学の統一及び科学的方法の普遍性

2. 諸科学の自律性、及び常識的合理性・社会的行為からの諸科学の明確な区別

3. 明確な前提に基づいた諸命題が論理的に構築されたシステム、としての科学理論

4. 非具現的で公平無私なものとしての科学理論

5 . 個人的出来事としての科学的理論化

反提言

1 . 諸科学の異種混成、及び科学的方法の局所的編成

2 . 科学的行為と、日常的推論 ·社会的相互行為の分離不可能性

3 '. 科学活動についての認知的な説明の不十分性

4 '. 利害関心があり具現的な、科学者・数学者の活動

5'. 本質的に社会的な現象としての科学活動[Lynch 1988:82]

リンチによれば、科学社会学者やエスノメソドロジストは、科学に関するシュッッの諸 主張を道しるべとして研究を行なっていった。そしてそのことが、逆にその主張への批判 を生みだし、その後に展開されていく諸々の科学研究を鼓舞したことになる。歴史的系譜 としてはこのことは正しい。リンチが指摘するように、科学の社会的研究を行なった者た ちは、シュッツの諸概念が実際の科学活動にはあてはまらないものであることを経験的に 例証していった。 
例えば、 K.クノール-セティナによれば、シュッツに基づきガーフィンケルが展開した 科学的合理性は、マートンによる「科学のエートス」に極めて似ている点で、同様の批判 にさらされることを述べている。更にその中では、「ガーフィンケルは、行為に決まりき って現れるルールについて語っているので、[行為に直接には関係しない「エートス」に ついて語った]マートンをはるかに越え出ている」[Knorr-setina 1981:32]として、ガーフィ ンケル（およびシュッツ）に多くの罪を帰せている。また、B.ラトゥーア＆ S.ウルガー は、以下のように述べている。

こうした[科学の定義をトートロジカルに行なう]策略はどちらかといえば一般的であるけれども、 シュッツのような著者によって用いられる時には特に際だつものである。シュッツは、作業中の科 学者の実際の実践を現象学的に記述するという公然とした(professed)目的を持っていたのである。 認識論者によって与えられた観念に馴染みの観察者なら、科学者の実践活動の中に、敬意に値すべ き言説の例を見定めることは容易である。かくして、科学者は、科学者なので科学的に作業をして いるように見えてくる。(中略) 我々の立場は、こうした科学と常識の区別が存在するのならば、そ の存在は経験的に例証されなければならないというものである。ゆえに、我々が科学活動を描いて いく際には認識論的概念を回避していく[Latour \& Woolgar 1979:153]。

ラトゥーア\&ウルガーによれば、シュッツのように「科学者は、科学者なので科学的に 作業をしている」というトートロジカルな定義をするのなら、結局、科学活動の内実が解 明されえないのであり、そうした定義を放棄した上で研究をしていく必要があることを主 張している。こうした主張から、実験室研究を行なっていった科学社会学者が、シュッツ によって定式化された科学的合理性によって実験室の活動を捉えようとするのは間違いで あると指摘していることがわかる。これらの主張に基づいて、リンチは、シュッツの提言 とみなせるものを定式し、その反対提言と対照させているのである。

\section{3.「科学的理論化の態度」を備えるものとしての科学活動}

しかしながら、道しるべとしてのシュッツが批判されていくという歴史的経緯によって は、その中で行われたシュッツ批判じたいが妥当であることは必ずしも引き出されない。 こうしたリンチのシュッツ批判には過剰な点があることが指摘されている[浜 1998]。本 稿にとって重要なのは、リンチは、シュッツが科学的理論化 (の態度)に関して主張した ことを、労働行為としての科学に当てはめて批判したという指摘である。つまり、シュッ ツにおいては、理論化とそれ以外の諸々の科学活動とでは、その性質が弁別的に異なるこ とになる。まずは、この指摘じたいの妥当性を確認しておきたい。この指摘を根拠づける 主張は実際シュッツの著作に直接に読み取ることができる。

しかし、理論的な思惟は、労働という性質をもった行為ではない。（中略）理論的な思惟は、確 かに（測定し、道具を操り、実験をするといったような）労働行為に基ついている。（中略）だが、 労働の世界の内部で遂行され、さらにその世界に属しているそれら諸々の活動は全て、理論化の条 件であるか、さもなければ理論化の帰結であって、理論的な態度それ自体に属するものではない。 それら諸活動は、理論的な態度から容易に切り離されうるのである[Schutz 1962=1985:59]。 
それゆえ、実験室活動の諸特徵を挙げ、それが単純に科学的理論化の態度とは異なるが 故にシュッツの提言が間違っているのだと非難するクノール-セティナやラトゥーア＆ウ ルガーの主張は、シュッツ理解としては端的に䛊っていると言う他ない。そうした主張は、 シュッツが、科学的理論化と労働行為としての科学を弁別的に区別したことをまるで考慮 に入れていないのである。この点に関してリンチは以下のように述べている。

理論化が実験室における労働行為から切り離されていることをシュッツは強調しているので、実 際の行為の観察ではシュッツの提言の「テスト」にはならないのである。

しかしながら、科学的理論化を構成している様々な条件が存在論的に言及されるという問題が依 然として残っているのである[Lynch 1988:80]。

ここから、リンチ自身は科学的理論化と労働としての科学の弁別的区別をシュッツが設 けていたことを把握した上で議論を組み立てていることがわかる。上記のような反対提言 を掲げるにあたって、リンチがこの区別を重要視しなかったのは、科学的理論化の諸特徴 が科学活動にも関連性を持たざるをえないことが明らかにされていたからである。よって、 科学の基礎づけ主義を問題にするのなら、本当に問うべきトピックはこの区別じたいの妥 当性なのである。このことに関するリンチの主張[ibid.:80-1]は示唆的なものに留まるが、 以下、それを二つの論点として定式し、それを経験的知見で補っておきたい。

第一の論点は、理論化以外の科学活動においても、シュッツの提言のような主張が科学 者自身によって言及されるということである。このことは、N.ギルバート\& $\mathrm{M}$.マルケイ による科学者へのインタビューから明らかである。彼らは、例えば、科学的真理がいかに 入手できるかについて自然科学者にインタビューしている[Gilbert \& Mulkay 1984=1990 :chap.3]。そこにおける彼らの分析の着目点は、自然科学者は科学的真理を説明する際に、 真理は観察に基づいて発見されるという考えを支持する語りである「経験主義的レパート リー」を好むにもかかわらず、真理の発見にまつわる諸々のコンティンジェンシーを念頭 においた語りである「偶然的レパートリー」を用いらざるをえないこと、そして一見した ところ対立するように思われる二つのレパートリーを両立可能にしていく説明実践が行な われることである。

ここで注目しておきたいのは、まず、「スペンサー理論の熱狂的な支持は『厳密に証拠 に基づいて』生じたとインタビューの最中で彼[自然科学者]がすでに強調した」[ibid. :198]とあるように、科学者自身が、労働行為においても、シュッツであれば「厳格な諸 基準に従って進行する一つの過程」[Schutz 1962=1985:64] と表現するような、科学的理論 化の弁別的特性に言及しているということである。

もちろん、このような場面での自然科学者の労働行為とは、科学者（自身）の活動が科 学的真理の追求に有効なものであることを正当化するという類いの行為である。そして、 諸基準に従っていることと、そうした基準に従っていると言うことは別々のことである。 よって、具体的に観察可能な行為において、厳格な諸基準が厳守されているのかどうかは また別の問題ということになる。とはいえ、こうした言及からすれば、シュッツが科学的 理論化の態度として定式化されたものが労働行為においては何の関係もない、と主張する ことはできない。そうした態度は、科学実践の一端において言及されている。つまり、単 
に科学的理論化の特性として主張できるばかりでなく、当の科学者の様々な実践の資源と もなっているのである。

第一の論点なども考えた上で提出することのできる第二の論点は「シュッツの著作では、 また、自然科学の活動において常識的知識が果たす役割がいくぶん曖昧である」[Lynch 1988:81]というものである。シュッツは、例えば「後者[科学的な思惟において使用される 用語と観念]は、錯綜した前科学的思惟の隠された諸含意を明らかにすることによって、 そうした思惟を判明なものに変えることをとりわけ必要とする」[Schutz 1962=1985:64]と 主張する。こうした主張が科学的理論化と労働行為としての科学の弁別的区別の後になさ れるのであれば、労働行為としての科学活動は錯綜した前科学的思惟に充ち満ちているこ とが含意されかねない。以下、この主張から生じる二重の問題を指摘しておきたい。

まず、第一に、この主張は、常識的合理性を強調するシュッツの主張との折り合いがよ くない。もし、常識的概念を単に科学的概念によって修正されるべきものとみなすのであ れば、それは「自殺」という概念にたいしてデュルケームがとったような常識に対する修 正主義的な態度と変わりないものとなってしまう。常識的概念は曖昧で、誤解に満ちてお り、厳密でも正確でもないものなので、科学的概念によって修正されねばならないものだ という扱いを受けることになる。シュッツの諸議論を考慮にいれるのなら、この主張は誤 解を招きやすいものであると思う。

第二に、もしもこの含意を受け容れるとすると、それは実験室研究の諸知見と齟䶣をき たすことになる。例えば、実験室の活動がその後の発表や論文と強く関係していることが ラトゥーア\&ウルガーによって指摘されている[Latour \& Woolgar 1979:75-81]。彼らは 「リテラリー・インスクリプション」という概念を提出し、科学実践に用いられるメモか ら論文にいたるまでの読み書きの過程に注目していく中で、言明のタイプを五つに分け、 そのタイプの特性がその言明の事実の程度に対応すると主張する。その分類の基準とされ るのは、(「〜と最近になって確証されてきている」や「かもしれない」などの限定句のよ うな）諸様相や（「私が思うに〜」や「あの実験グループの主張によれば〜」といった） 著者性である。そうした諸様相や著者性を言明から取り外していくことが、論文執筆によ って完成するまでの一連の科学活動ということになる。

ラトゥーア\&ウルガーによる、このような言明タイプへの焦点化において、ここで注目 したいのは以下の点である。まず、実験室の活動は、局所的な知識から普遍的知識への改 変作業として特徴づけられている(3)。それゆえ、このように指摘された実験室活動の特徵 は、むしろ、シュッツが科学的理論化の態度において述べ、また、そこで参照されている 社会科学方法論とも結びつくものである。例えば、ラトゥーア\&ウルガーによる実験室活 動の特徴づけを、「直接的で原的な諸体験」の表現としての言明と両立可能なかたちでそ の言明の事実的地位を上げていく作業とみなすことは可能であろう。また、そうした言明 の変換過程こそ「科学的な手続きに関する厳格な諸基準に従って進行する一つの過程」 [Schutz $1962=1985: 64]$ なのだと主張することもできると思う。

また、実験室活動へのラトゥーア\&ウルガーの焦点の合わせ方は、明らかに、実験室活 動という労働行為と、論文執筆の過程に代表される科学的理論化を弁別可能な特性によっ て排他的に区別してはいない。むしろ、彼らは両者を一連の過程として特徵づけている。 これらの点を踏まえれば、やはり、科学的理論化だけによって、科学が科学たる弁別的特 
性を背負わせるには無理がある。もちろん、そうであるからと言って、労㗢行為としての 科学にはシュッッの言う「科学的理論化の態度」しかないというわけではない。そうした 主張はまた、実験室のエスノグラフィー研究の他の知見と婳龉をきたすことになる。

よって、この二つの論点から確認できることは二つある。一つは、労衝行為としての科 学の中にも「科学的理論化の態度」が入り込んでいることである。もう一つは、仮にも労 働行為としての科学と科学的理論化の弁別的な区別を主張するのであれば、その区別の妥 当性じたいは、概念定義によってもたらされるものではないということである。それは、 既に成し遂げられている、理論化も含めた科学実践をつぶさに見ていくという経験的研究 によって明らかにされるべき事柄なのである。

\section{4. 科学的理論化の日常性}

さて、ここまで、労働行為としての科学において科学的理論化の態度が関係することを 論じてきた。よって今度は、まず、科学的理論化それ自体を一つの実践として経験的に例 証していきたい。その上で、その例証からこの区別の妥当性について検討したい。

ところで、この労働行為としての科学と科学的理論化の弁別的な区別は、シュッッによ る科学と日常性の区別に由来している。もちろん、先に述べたように、この区別が社会学 において果たした役割を軽視することはできない。この区別こそが常識的合理性それ自体 を解明していく方向性を与えたのであり、この方向性自体はガーフィンケルによって受け 継がれていったものでもある[Garfinkel 1967:Chap.2]。しかし、こうした弁別的な境界設 定こそ、エスノメソドロジーにおいて問題視されてきたものである。そうした境界設定に よって含意されがちな科学的特権こそ、科学のエスノメソドロジーが否定してきたものな のである。

では理論化とは、そもそもどのような活動なのか。ライルは、コロンブスの航海やケプ ラーの観察を挙げて、理論構築が机上の作業に限定されないことを論じている[Ryle 1949=1987:423]。また、実践理論などという言葉を思い浮かべれば容易にわかるように、 理論化は科学の独占物ではない。日常活動の中に理論はいくらでもある。とはいえ、こう した理論の日常性だけでは、科学における理論の弁別性の主張の論駁にはならない。実際 シュッツは、こうした理論化とは異なるものとして科学的理論化について論じているので ある[Schutz 1962=1985:58-9]。それゆえ、シュッツの弁別的区別を検討するのであれば、 科学的理論化を探究対象としなければならないのである(4)。

\section{（1）理論化作業：記号読解の実践}

では、科学的理論化それ自体を検討していきたい。ここでは、社会学における理論化を 科学的理論化の一例とみなし、その一つとして「記号読解の実践」に注目する。あらかじ め述べておけば、正確な概念定義などではなく、この実践こそが理論的構成概念の実在性 を、記号と指示対象の関係を逆転的に利用することによって実際上構築しているのである [Baccus 1986]。この記号読解の実践のきわめて典型的なものとして、デュルケームの『自 殺論』の一節「自己本位的自殺」[Durkheim 1897=1985:171-259]を取り上げたい(5)。周知 のように、『自殺論』におけるデュルケームの基本的目的は、個人的ではなく社会的な、 自殺の原因を解明することにあった。 
まず最初に注目すべきことは、自然言語としての自殺を科学的に修正した上で分類され た項目の一つである「自己本位的自殺」はもちろん、その統合・不統合が論じられる「社 会」も同じように理論的構成概念であるということである。この「社会」という理論的構 成概念はこの著作において特有の地位を占めている。そして、この二つの概念の関係こそ デュルケームの証明したい点である。

次に、デュルケームは、自然言語において既に秩序だって用いられている自殺という概 念を、曖昧であるとして科学的に修正しながらも、この概念が持つそもそもの特有性は保 持したことである。その特有性とは、この概念が、それによって示されている対象の直接 的な観察可能性をかなりの程度削りとっているというものである。つまり、自殺という行 為はなかなか目撃できないものであり、死体による特定は必ずしも確実とは言えないとい うことである。よって、この理論的構成概念の可視化には、自ずと指標が利用可能でなけ ればならないことになる。実際デュルケームはいくつかの指標を用いた。これらの利用可 能性をとおして、「自己本位的自殺」そして「社会」は現実のものとなっていく。以下、 このことがいかに達成されるのかをごく簡単に検討したい。

「自己本位的自殺」の指標として用いられるのは自殺者数である。しかし、記録上の自 殺者数は「自己本位的自殺」をした者の数などではない。にもかかわらず、(この節での) 自殺者数は「自己本位的自殺」の指標として想定される。この想定を ‘現実’のものとす るには、すなわち、この理論的構成概念を産出するためには「著者は、読み手にとっては 既にお馿染みのものである、より一般的な人物／出来事カテゴリーに、自らの研究の個々 の対象を結びつけなければならない」[Gusfield 1976:25]。この節でデュルケームが行った 社会学的推論は、自殺者を何らかの「社会集団」の成員として割り当てることである。

社会集団として第一に用いられるのは宗教である。ここで、ある宗教教団に籍を置く者 ならどんな者であれ、その宗教「社会」の成員としてカテゴリー化される。このことの含 意はかなり強い。なぜなら、書かれたものを意味あるものとして読解していこうとする限 り、その成員が担うことのできる他のカテゴリーは、さしあたり脇へ寄せられるからであ る。そして各宗教に「社会集団」としてのその特性が付与され、その特性が自殺行為と関 連づけられることによって「自己本位的自殺」が語られる。「自己本位的自殺」も集団と しての宗教「社会」も、他なら好経験的証拠であると想定可能なものとして導入され た自殺数、及び宗教の特性を通して始めて観察可能なものとされる。つまりは、そうした 指標の使用を通して、空想の産物ではなく、世界に実在するものとされるのである。

このような概念の実在は、通常は疑問視されることのない、物理的対象の「素朴な実在」 と同様に考えることはできない(6)。つまり、個々の自殺数が「自己本位的自殺」となるの は、「社会集団」の（不統合という）特性を自殺行為の原因として、統計上確認できる自 殺者に帰属させるという実践を叙述において達成することによってなのである。仮にこの ような実在を是認するにしても、それと常に同時に行われなければならない、この、実在 を実在たらしめている実践を実在と切り離して考えることはできないのである。

また、宗教「社会」の自殺者数だけが「自己本位的自殺」の指標となるわけではない。 ここで特有に用いられている「社会」概念は家族と政治にも適用される。つまり、どちら の「社会」も「集団」としての観点から特定化され、そのことが自殺行為と結びつけられ る。「社会」および「自己本位的自殺」という概念双方が宗教特有のものとしてだけ実在 
するのではなく、遍在することを示すことによって初めて、それらの一般性、及びその確 固たる実在性を主張できるのである。

それゆえ、いくつもの「観察可能な」指標を並べることができたので、これら理論的構 成概念の実在性が確保されたという主張の含意はそれほど素朴なものではない。理論的構 成概念というものは指標とは別個に存在するものなのだということ、つまり、指標とされ たものがまさに何らかの理論的構成概念の指標であること、このことを納得のいくものと して指し示すには、いくつかの指標を用いることが非常に有効に作用するということなの である。宗教、家族、政治に「社会」集団としての一貫した特性があることを示すことに よって、「社会」、そしてここでは「自己本位的自殺」が、それぞれの「集団」に出現しな がらも、そのそれぞれとは独立に実在することが主張できるのである。

かくして、以下のようにまとめることができる。理論的構成概念の実在性は、観察可能 な現象をその概念の指標として利用できるように配置する叙述を構成すること、すなわち 記号読解の実践によって獲得される。指標の数值はその実践に対して補助的に作用するの であって、それ以上のことを行い得るものではない。

また、ここでの指標と理論的構成概念に割り当てられた記号と指示対象の関係を、理論 的構成概念どうしの関係にもデュルケームが適用したことは、彼のこの実践への依存のほ どを明らかにしてくれる。彼は、宗教・家族・政治などを「社会」集団として捉えること だけによって「社会」の実在性を唱えたのではない。彼にとって、自殺行為とは「当の社 会的状態を外部的に表現」(強調は本著者）しているものなのである。「自己本位的自殺」 は実在するものとして構築されるだけでなく、今度はこの特有の「社会」概念の実在を保 証することになる一つの指標として、「集団本位的自殺」や「アノミー的自殺」とともに 用いられていくのである。

\section{（2）記号読解の実践の日常性}

さて、ここでこの実践を取り上げたのは、科学的理論化と労働行為としての科学の弁別 的な区別の観点からこの実践を位置づけるためである。まず、こうした記号読解の実践は 学問においてのみなされるようなものではない。例えば、この実践は、ガーフィンケルが 論じた自殺防止センターにおける実践と形式的な類似点を持つ[Garfinkel 1967:11-8]。ガ ーフィンケルが注目した自殺防止センターの実践とは、（自殺か他殺かはっきりしないよ うな）「突然の不自然な死」を少なからず確定していく作業であった。まず、こうした死 のケースは端的に観察可能なものではありえない。よって、この実践は、「その死に関係 する」と理解可能/観察可能な遺品や逸話を繋ざあわせていく作業なのである(7)。そして、 この作業の特性として挙げられているさまざまなものから、ここで注目したいのは「死を、 先行する事実(precedant)として扱う」というものである。

ある死体がどの死によってもたらされたのか。実践者は、しばしばこのことを予め想定 した上で調査を行っていく。そして、そのように想定された死を指し示すものとして理解 可能な遺品や逸話が焦点化され、またそれが前提となって更なる探求が繰り広げられてい くのである。つまり、いくつもの既に挙げられている遺品や逸話の中でいったい何がその 死に関わるものであるのか、その他にも探しだされるべきものはどのようなものなのか、 関わりあるものとして挙げられたさまざまな遺品や逸話はいったいどんな関わりを持つの 
か、こうしたことは、しばしば、予め特定の死を想定した上でなされていく。

このようにして、予め特定の死を想定した上でその証拠となるものを焦点化する作業は、 先に論じた記号読解の実践と同様の形式的特性を持っている。つまり、この場合ならば、 想定上の特定の死に、その不可視性のゆえに先に理論的構成概念が占めていた地位を授け ることができる。そして、焦点化されていく遺品や逸話には、その可視性および特定の死 を指し示す役割を果たしているがゆえに、指標の地位を授けることができるのである。

もちろん、この二つの事例は自殺という自然言語に関わるものであり、この概念の用い られ方に依存するところは大きい。しかし、ここで主張したいのは記号読解の実践の特有 性よりもむしろ、その日常性--他の実践との共通性--である。よって、この実践が、直接 には観察不可能なものを可視化する際に使われてきた実践と類似するものであることを述 べておきたい。

記号読解に類似する実践として予測や説明について考えてみたい。例えば天気予報は、 統計学的なデータに基づいて出される予測である。この場合、現在の大気の状況という観 察可能な事態から、未来の大気の状況（そして、未来の天気）という観察不可能な事態を 予測する。ここで注目しておきたいのは、天気予報はその未来が現在として訪れた時点で 間違いであったことが判明することもあるということである。もちろん予測の是非をめぐ っては、解釈の多様性が入り込む場合がある。とはいえ、予測の方法が論理的に説明可能 /反証可能である度合が高ければそれだけ、その予測と予言との区別は際立つ。

予測と説明は構造を同じくするものの、予測は未来志向であり説明は過去志向である点 で大きく異なる。つまり、予測の場合は原因に観察可能性、結果に観察不可能性が付与さ れる一方、説明の場合には原因に観察不可能性、結果に観察可能性が付与される。

こうした説明の構造は、なにも天気予報のような現代科学を駆使した領域に限定される ものではない。それはもっとプリミティヴな日常レヴェルにおいても見ることができる。 例えば、登山者なら誰しも暗雲から雨を予測する。この関係は、統計的蓋然性に基づいた 因果性を持つことが一般に知られてはいるものの、因果性を超えて規範的期待を持つこと がある。例えば「暗雲があるのにどうして未だに雨が降らないのか」といった具合である。

規範的期待は事実の是非に関わらず維持されるわけだが、この期待から観察不可能な過 去の事実が導き出されることがある。この時、予測は説明に代わる。そして、この規範性 があからさまにならなければそれだけ一層、そうした過去の事実の導入は「憶測」として は語られず、事実的地位を強くする。このことを上記の例で考えるのなら「雨が降るのな ら暗雲があったのだ」といったことになるであろう。そしてその際には、暗雲の実在が観 察によらずに措定されるようになっている。そうした推論の形式が、観察不可能な対象の 実在を主張できるものとしていく。つまり、規範的期待が付着した「原因」としての暗雲 について、その観察不可能性は問題あるものとはされないのである。

それゆえ、記号読解の実践は、観察不可能なものの可視化という点で上で取り上げたよ うな説明と類似する。両者の相違は、記号読解の実践が記号と指示対象の関係を利用して いる一方で、上記の説明が経験則に基づいた因果関係の規範化に依存している点である。 このことからすれば、記号読解の実践とは、科学的理論化に何ら限定されるものではない し、実践的推論を明確に／厳密に更新したものでもない。むしろ、この実践は、直接的に は観察不可能なものを可視化する諸々の実践の中に位置づけることができる。よって、記 
号読解の実践が社会学の理論化作業の特性として把握できる以上、科学的理論化は日常実 践と弁別的に区別できるものではない。それゆえ、こうまとめて良いだろう。日常実践の 特性を保持するとされる労働行為に扔ける科学加も、科学的理論化は何ら弁別的に区別 されるべきものではない、と(8)。

\section{5. 結}

以上、科学的理論化と労㗢行為としての科学の弁別的な区別について論じてきた。その 際、本稿は二つのアプローチをとった。一つは、実験室の実践についての既存の研究の知 見を用いることで、この労働行為においても「科学的理論化の態度」が含まれることを論 じた。もう一つは、科学的理論化という実践それ自体を検討することによって、そこから 抽出した方法実践が日常的なものであることを論じた。この二重の論証によって、科学的 理論化と労働行為としての科学を弁別的に区別することが不可能であることを示した。

この論証が、シュッツ科学論の批判となるのは言うまでもない。しかし、ここで主張し たいのは、日常活動の常識的合理性を強調したシュッッでさえもこのような批判に晒され ざるをえないということである。この批判はシュッツ科学論の批判にとどまるものではな い。自らの学問実践を科学の名の下に根拠づけようとするどんな言明もこの批判を免れう るものではない。そして、そうした言明は社会学においても支配的なものである。

この論証に基づいた批判によって科学の不可能性を主張するのは簡単なことであるが、 既に科学という名の下に学問実践が織り成されているという事実はそれでも残る。また、 この批判は、明らかに、基礎づけによって自らの主張を根拠づけようという態度に向けら れている。常識と弁別的に区別可能であるがゆえに特権的な地位を持つ科学などというも のはもはやない。そして、それにもかかわらず、我々は扔互いの研究成果を理解可能なも のとしている。これらのことからすれば、基礎づけ問題は疑似問題である。この論証は、 基礎づけ問題の解消をもたらしているのである。よって、基礎づけ主義もありえない。

この基礎づけ主義の消滅は二つの研究の方向性を示している。一つは、常識的概念に関 わるものである。もはや我々は、これまでの社会学が採用してきた、常識的概念にたいす る修正主義的な態度をとるべきではない。そうではなく、常識的概念それ自体の用いられ 方をそれが用いられる場面にそくして記述していくという新たな方針をとるべきである。 会話分析の創始者ハーヴィー・サックスは、『自殺論』を取り上げて、早くからこのこと を主張している。「自殺というカテゴリーを記述し終えるまでは、つまり、この種類のも のとなる事例を集めるために用いられている手続きの記述をし終えるまでは、いくらかで あれ、このカテゴリーが社会学の装置となる可能性すらないのである」[Sacks 1963:8]。

いま一つの方向性は既存の研究の理解可能性に関わるものである。既にこれまで行われ てきた諸々の学問は、弁別的な区別によってもたらされた基礎づけによって確固たるもの となっているわけではないことをこれまで論証してきた。ならば、我々はお互いの研究成 果をいかにして理解可能にしているのか、このことこそ問うべき事柄なのである。方法論 が要請する事柄とは別様な日常的実践によって科学は織り成されている。そうしたあり様 こそ、未だに明らかにされていない領域なのである。つまり、この方向性は学問的営為そ れ自体の探究を促す。そして、本稿で取り上げた記号読解の実践も、こうした探究の一つ として位置づけることができる。記号読解の実践は、理論化作業の理解可能性を支える一 
つの資源なのである。こうした資源、及びその用いられ方が理論化を可能にしている。 シュッツは科学的合理性が「日常生活における人間行為を解釈する際の方法論上の原理 ではありえない」 [Schutz 1964=1991:117]ことを早くから述べていた。しかしガーフィン ケルは、この主張を受け継ぎながらも、科学的合理性を理論化に閉じ込めるのではなく 「経験上問題のある素材としてだけ扱われねばならない」[Garfinkel 1967:282]としたので ある(9)。こうした経験的研究の方向性こそ、ここで論じた科学と日常性の弁別的区別の解 消に繋がるものである。こうした意味で、この後に行われていく科学のエスノメソドロジ 一研究の方向づけは、シュッツによる概念定義を経験的に問うていく作業の中に既にある。 科学のエスノメソドロジー研究とは、科学方法論の中に閉ざされていたトピック--観察、 測定から、概念定義、理論化まで--を実践として捉えていく試みなのである。そして、本 稿における論証もこの方向性を一歩押し進めていくものに他ならない。

註

(1) ここで取り上げていくシュッッの科学論はシュッッ自身の立場ではなく、構成的現象学というシュ ッツの方法による分析である、という指摘もある[浜 1998]。この指摘の包括的検討は著者の能力を越 え出ているが、シュッツ科学論じたいの妥当性に関するものとしては、本稿の問題設定は理に適った ものである。また、[西阪 1998]参照。

(2) なお、ここでリンチが取り上げている研究が対象としているものは、ほとんどが自然科学である。 確かに、自然科学と社会科学では、何をもって自らを基礎づけるのかに関して差異があることもある。 ただし、基礎づけ主義的な態度をとること自体はどちらも変わるところがない。本稿は、さしあたり そのレヴェルでの議論を展開している。

(3) もち万ん彼らの特徵づけは、彼ら自身認めるように、形式的なものであり、場面の一構成要素とし てある言明がその都度どう扱われているのかにたいする配慮がたりない。これに関しては、例えば [Lynch 1993:chap.3]を参照。

(4)「伝達のパラドックス」[Schutz 1962=1985:72]というシュッッの主張について述べておきたい。シ ユッツによれば、理論家の科学的理論化作業は孤独なものであるが、そこからその理論的思惟がいか にして伝達されるのかという問題が生じることになる。伝達のパラドックスがパラドックスたりうる のは理論的思惟が超越論的領域における問題である限りであるわけたが、これに対するシュッツの主 張はあまり一貫していないように思われる。少なくとも私は「個人を単位とする存在論」[Coulter 1979=1998:48]ではなく、日常言語の公的な理解可能性を出発点に据えるので、科学的理論化が孤独な ものであることは伝達のパラドックスを生まない。しかし、この点でシュッッの主張を拒否したとし ても、科学と日常性の弁別的な区別という論点は解明されるべきものとして残るのである。

（5）以下の分析じたいは[中村 1997]よりの抜粋である。ただし、修正を加えたばかりでなく、その含意 については本稿において拡張したものである。

(6) もっとも、素朴な実在ですら、ある一定の記述の下に見るという点では概念負荷的であり、素朴と 片づけてしまうのは危険だが、解釈を要しないという意味では素朴である。

(7) この点は[Atkinson 1978]によって掘り下げられている。また、[中河 1999:chap.2]参照。

(8)この主張にたいして、シュッッは理論化の産物については述べておらず、理論化作業における個人 の意識としての科学的理論化-理論的思惟-についてのみ論じていたという批判があるかもしれない。 しかし、もしそうならば、シュッツは、作業から分離可能な意識なるものをその作業の構成的特性と して想定していた点でそもそも誤っていることになる。ここでは、そのようなシュッツ解釈は避けた。 また、本稿のシュッツ科学論批判をある程度先取りしたものとして[矢田部 1998]を挙げることができ る。矢田部が言うように、科学と常識の弁別的区別に適用条件を設けることが認められるのであれば、 本稿の論証はシュッツ批判にはならない。そうした作業じたい、シュッツの更なる可能性を導きだす 試みであるが故に画期的である。とはいえ、矢田部が言うように、科学と常識の弁別的な区別を「行 
為者」がたてる「モデル」にすぎないものと考えるのであれば、いったいそうしたモデルがどのよう な実践においてそもそもたち現われてくるのかを解明しなければならないことになる。つまり、ある カテゴリーやカテゴリー対は状況的に達成されるものである以上、そのような場面性・状況性を超越 するような一般的妥当性を含意するモデルというものの地位を不問に帰すことはできない。また、労 働としての科学と科学的理論化のような分析的区別がシュッツの著作を越えて関連性を持つ場面は、 なかなか想像しがたい。いずれにせよ、常識と科学の区別を設けたシュッツの主張にはそうした状況 性を示唆する点があるとするのなら、それは革新的な解読だと思われる。とはいえ、そうした解読の 是非は著者の能力を越え出ている。

(9) 従って、ガーフィンケルのシュッツ解釈の「ねじれ」[中村 1996:76]は、（論理的ではなく）経験的 な事柄に関してはその研究に先立った概念定義に依存しない、という方針に限定されるべきである。 この点を示唆して頂いたことに匿名のレフェリーに感謝します。

付記：本稿執筆にあたって、上谷香陽 (日本学術振興会特別研究員)、皆川満寿美（武蔵大学他非常勤講 師）の両氏に有益なコメントを頂きました。記して感謝の意を表します。

\section{文献}

Atkinson,J. 1978 Discovering Suicide. Macmillan.

Baccus,M. 1986 "Sociological indication and the visibility criterion of real world social theorizing" ,in Garfinkel(ed) Ethnomethodological Studies of Work. Routledge.:1-19.

Durkheim,E. 1897 Le Suicide. 宮島喬（訳）『自殺論』中公文庫 1985

浜日出夫 1998 「シュッツ科学論とエスノメソドロジー」 日本現象学・社会科学会研究例会報告レジ ユメ

Garfinkel,H. 1967 Studies in ethnomethodology. Prentice-Hall.

Gusfield,J. 1976 "The literary rhetoric of sciences: comedy and pathos in drinking driver research" in American Sociological Review (41):16-34.

Knorr-Cetina, K. 1981 The Maufacture of Knowledge : an essay on the constructivist and contextual nature of science. Pergamon Press.

Latour, B. \& Woolgar, S. 1979 Laboratry Life : The social construction of scientific facts. Sage.

Lynch,M. 1988 "Alfred Schutz and the Sociology of science" ,in Embree,L(ed.)Worldly Phenomenology. Center for Advanced Research in Phenomenology \& University Press of America.:71-100.

Lynch,M. 1993 Scientific Practice and Ordinary Action. Cambridge.

中河伸俊 1999 『社会問題の社会学 -構築主義アプローチの新展開-』世界思想社

中村和生 1996 「エスノメソドロジー的関心：科学の日常性」『現代社会理論研究』第 6 号:73-86.

中村和生 1997 「理論化作業の実践学的探究」年報（関東社会学会）第10号:181-192.

西阪 仰 1998 「リプライ」『現代社会理論研究』第 8号:264-265.

Ryle,G. 1949 The Concept of Mind. 坂本百大·宮下治子・服部裕幸（訳）『心の概念』みすず書房 1987

Sacks,H. 1963 “Sociological Description”, in Berkeley Journal of Sociology (8):1-16.

Schutz,A. 1962 Collected Papers I 渡部光·那須壽・西原和久（訳）『社会的現実の問題 I』『社会的 現実の問題 II 』マルジュ社 1983

Schutz,A. 1964 Collected Papers II 渡部光・那須壽・西原和久（訳）『社会理論の研究』マルジュ社 1991

矢田部圭介 1998 「意味とワーキング」 西原和久他（編）『現象学的社会学は何を問うのか』勁草書 房:144-166.

(明治学院大学・非常勤講師) 